\title{
ANALISIS KADAR ARSEN (As) DAN TIMBAL (Pb) PADA MINYAK GORENG PEMAKAIAN BERULANG DENGAN METODE SPEKTROFOTOMETRI SERAPAN ATOM
}

\author{
Aminah, Rahmawati, Tadjuddin Naid, Salma \\ Fakultas Farmasi Universitas Muslim Indonesia Makassar \\ Email : aminah.aminah@umi.ac.id
}

\begin{abstract}
This study aims to analyze the levels of arsenic (As) and lead (Pb) in frying oil usage over and over. This research was conducted at the Center for Health Laboratory Makassar. Samples obtained from merchants fried foods. To ensure the metal content of the samples prior didestruksi with $\mathrm{HNO}_{3} \mathrm{P}$ and heated for 16 hours to liberate arsenic and lead from the oil matrix, then measured using atomic absorption spectrophotometer (AAS) at a wavelength of $193.7 \mathrm{~nm}$ (Arsenic) and 283 $\mathrm{nm}$ (lead). From the results obtained penilitian arsenic (As) in the three vendors that is <0.1 ppm (max 0.1 ISO ppm) and lead levels that merchants 1 (0.1503 mg / kg and $0.1940 \mathrm{mg} / \mathrm{kg})$, traders $2(0.3452 \mathrm{mg} / \mathrm{kg}$ and $0.4005 \mathrm{mg} / \mathrm{kg})$, the merchant 3 $(0.1111 \mathrm{mg} / \mathrm{kg}$ and $0.1788 \mathrm{mg} / \mathrm{kg}$ ) respectively for the samples before and after frying (SNI max $0.1 \mathrm{mg} / \mathrm{kg}$ ).
\end{abstract}

Keywords: Cooking oil, arsenic, lead, atomic absorption spectrophotometry.

\section{PENDAHULUAN}

Minyak goreng didefinisikan sebagai minyak yang diperoleh dengan cara memurnikan minyak nabati. Minyak nabati merupakan minyak yang diperoleh dari jagung, gandum, beras, kacang-kacangan (kacang kedelai, kacang tanah, dan lain-lain) palma-palmaan (kelapa dan kelapa sawit), dan biji-bijian (biji bunga matahari, biji wijen, biji teng kawang, biji kakao, dan lain-lain. ${ }^{3}$

Minyak penting dalam proses penggorengan bagi industri makanan gorengan. Ada masyarakat yang menggunakan minyak goreng hanya untuk sekali pakai, namun ada juga yang menggunakan minyak goreng berulang. ${ }^{4}$

Kegiatan manusia yang mampu melepaskan arsen menuju udara berasal dari abu hasil letusan gunung berapi, asap kebakaran hutan, serta dari berbagai kegiatan industri (industri pertanian dan industri peralatan listrik. ${ }^{5}$

Sumber pencemaran logam berat terbesar dari asap kendaraan bermotor yakni mencapai 60\%-70\%. 
Analisis kadar Arsen (As) dan Timbal (Pb) pada minyak goreng pemakaian berulang dengan metode Spektrofotometri Serapan Atom

Semakin padatnya kendaraan yang menggunakan bahan bakar bensin maka kadar timbal $(\mathrm{Pb})$ dalam udara juga meningkat karena bersifat akumulatif. $^{2}$

Hasibuan, dkk (2013) telah meneliti tentang minyak goreng sebelum dan sesudah penggorengan dimana terdapat cemaran logam timbal $(\mathrm{Pb})$ yang tidak memenuhi syarat yaitu 0,3091 ppm sebelum penggorengan dan $0,8216 \mathrm{ppm}$ sesudah penggorengan dimana batas maksimum yang dipersyaratkan oleh SNI yaitu $0,1 \mathrm{ppm}^{2}$

Chairunisa (2013) telah meneliti tentang cemaran logam pada minyak goreng yaitu logam kadmium (Cd) $0,0001 \mathrm{mg} / \mathrm{kg}$ dengan $\mathrm{SNI} \leq 0,2 \mathrm{mg} / \mathrm{kg}$ dan timbal $(\mathrm{Pb})$ 0,0004 $\mathrm{mg} / \mathrm{kg}$ dengan $\mathrm{SNI} \leq 0,1 \mathrm{mg} / \mathrm{kg}{ }^{1}$

Logam berat dapat menimbulkan efek toksik yang mampu menghalangi kerja enzim sehingga mengganggu metabolisme tubuh yang menyebabkan alergi, bersifat mutagen, teratogen atau karsinogen bagi manusia maupun hewan. ${ }^{5}$

\section{METODE PENELITIAN}

\section{Alat dan bahan}

Alat-alat gelas (pyrex), hot plate, kertas saring Whatman, neraca analitik (Ohaus tipe pioner),
Spektrofotometer Serapan Atom (Varian AAS GFA 7000).

Bahan yang digunakan air suling, asam nitrat p.a (E.Merck), arsen nitrat, timbal (II) Nitrat, minyak goreng.

\section{Prosedur kerja}

\section{Proses Destruksi}

Ditimbang 10 gram minyak goreng, dimasukkan ke dalam gelas kimia $100 \mathrm{~mL}$ ditambahkan $15 \mathrm{~mL}$ larutan $\mathrm{HNO}_{3}$ p.a dan dipanaskan di atas hot plate pada suhu $250^{\circ} \mathrm{C}$ selama 16 jam. Diencerkan dengan air suling hingga $50 \mathrm{~mL}$ ke dalam labu takar kemudian disaring menggunakan kertas saring Whatman. Filtrat yang diperoleh digunakan untuk analisis logam arsen dan timbal. ${ }^{6}$

\section{Analisis Kuantitatif ${ }^{6}$}

\section{Pembuatan Kurva Kalibrasi}

\section{Larutan standar As 10 ppm}

Dipipet $5 \mathrm{~mL}$ larutan standar 1000 ppm, diencerkan dengan $\mathrm{HNO}_{3}$ $P$ hingga $50 \mathrm{~mL}$ (100 ppm). Kemudian dipipet $10 \mathrm{~mL}$ larutan standar 100 ppm, di encerkan dengan $\mathrm{HNO}_{3} \mathrm{P}$ hingga $100 \mathrm{~mL}$ (10 ppm).

\section{Larutan standar 5,10, 15 dan 20 ppm}

Dipipet masing - masing 25, 50, 75 dan $100 \mathrm{~mL}$ larutan standar 10 ppm, diencerkan dengan $\mathrm{HNO}_{3} \mathrm{P}$ hingga $50 \mathrm{~mL}$, sehingga diperoleh konsentrasi 5,10, 15 dan 20 ppm. 
Analisis kadar Arsen (As) dan Timbal (Pb) pada minyak goreng pemakaian berulang dengan metode Spektrofotometri Serapan Atom

diukur konsentrasi logam arsen pada panjang gelombang 193,7 nm.

\section{Larutan standar Pb 10 ppm}

Dipipet $5 \mathrm{~mL}$ larutan standar 1000 ppm, diencerkan dengan $\mathrm{HNO}_{3}$ $P$ hingga $50 \mathrm{~mL}$ (100 ppm). Kemudian dipipet $10 \mathrm{~mL}$ larutan standar 100 ppm, di encerkan dengan $\mathrm{HNO}_{3} \mathrm{P}$ hingga $100 \mathrm{~mL}$ (10 ppm).

Larutan standar 0,$5 ; 1 ; 1,5 ; 2 ;$ dan 5 ppm

Dipipet masing - masing 2,5; 5; 7,$5 ; 10$ dan $25 \mathrm{~mL}$ larutan standar 10 ppm, diencerkan dengan $\mathrm{HNO}_{3} \mathrm{P}$ hingga $50 \mathrm{~mL}$, sehingga diperoleh konsentrasi 0,$5 ; 1 ; 1,5 ; 2$; dan 5 ppm. Diukur konsentrasi logam timbal pada panjang gelombang $283 \mathrm{~nm}$.

\section{Analisis Logam dalam Sampel}

Larutan sampel hasil destruksi diukur absorbansinya dengan Spektrofotometer Serapan Atom, untuk logam As pada panjang gelombang 193,7 nm dan untuk logam $\mathrm{Pb}$ pada panjang gelombang $283 \mathrm{~nm}$.

\section{HASIL PENELITIAN}

Tabel 1. Hasil Pemeriksaan Kadar Arsen (As) Pada Minyak Sebelum dan Sesudah Penggorengan

\begin{tabular}{cccccc}
\hline \multirow{2}{*}{ Pedagang } & \multicolumn{2}{c}{ Sebelum penggorengan } & \multicolumn{2}{c}{ Sesudah penggorengan } & \\
\cline { 2 - 5 } & $\begin{array}{c}\text { Berat sampel } \\
(\mathbf{m g})\end{array}$ & $\begin{array}{c}\text { Kadar } \\
(\mathbf{p p m})\end{array}$ & $\begin{array}{c}\text { Berat sampel } \\
(\mathbf{m g})\end{array}$ & $\begin{array}{c}\text { Kadar } \\
(\mathbf{m g} / \mathbf{k g})\end{array}$ & Ket \\
\hline 1 & 10,745 & $<0,01$ & 10,692 & $<0,01$ & MS \\
2 & 10,688 & $<0,01$ & 10,361 & $<0,01$ & MS \\
3 & 10,345 & $<0,01$ & 10,316 & $<0,01$ & MS
\end{tabular}

Standar maksimal logam arsen (As) adalah $0,1 \mathrm{mg} / \mathrm{kg}$ pada minyak goreng.

Ket : ppm = part per million

$\mathrm{MS}=$ memenuhi syarat

TMS = tidak memenuhi syarat

Tabel 2. Hasil Pengukuran Serapan Larutan standar pada logam arsen (As) Pada Panjang Gelombang 193,7 nm

\begin{tabular}{cc}
\hline Konsentrasi (ppm) & Absorbansi \\
\hline $\mathbf{5 , 0}$ & 0,0120 \\
$\mathbf{1 0}$ & 0,0210 \\
$\mathbf{1 5}$ & 0,0339 \\
$\mathbf{2 0}$ & 0,0418 \\
\hline
\end{tabular}


Analisis kadar Arsen (As) dan Timbal (Pb) pada minyak goreng pemakaian berulang dengan metode Spektrofotometri Serapan Atom

Tabel 3. Hasil Pemeriksaan Kadar Timbal (Pb) pada minyak goreng sebelum dan Sesudah penggorengan

\begin{tabular}{cccccc}
\hline Pedagang & \multicolumn{2}{c}{ Sebelum penggorengan } & \multicolumn{2}{c}{ Sesudah penggorengan } & \\
\cline { 2 - 5 } & $\begin{array}{c}\text { Berat sampel } \\
\mathbf{( m g )}\end{array}$ & $\begin{array}{c}\text { Kadar } \\
\mathbf{( m g / k g )}\end{array}$ & $\begin{array}{c}\text { Berat sampel } \\
\mathbf{( m g )}\end{array}$ & $\begin{array}{c}\text { Kadar } \\
\mathbf{( m g / / k g )}\end{array}$ & Ket \\
\hline 1 & 10,745 & 0,1503 & 10,692 & 0,1940 & TMS \\
2 & 10,688 & 0,3452 & 10,361 & 0,4005 & TMS \\
3 & 10,345 & 0,1111 & 10,316 & 0,1788 & TMS
\end{tabular}

Standar maksimal logam timbal $(\mathrm{Pb})$ adalah $0,1 \mathrm{mg} / \mathrm{kg}$ pada minyak goreng.

Ket : ppm = part per million

$\mathrm{MS}=$ memenuhi syarat

TMS = tidak memenuhi syarat

Tabel 4. Hasil Pengukuran Serapan Larutan Standar pada logam timbal (Pb) Pada Panjang Gelombang $283 \mathrm{~nm}$

\begin{tabular}{cc}
\hline Konsentrasi (ppm) & Absorbansi \\
\hline $\mathbf{0 , 5}$ & 0,0103 \\
$\mathbf{1}$ & 0,0222 \\
$\mathbf{1 , 5}$ & 0,0308 \\
$\mathbf{2}$ & 0,0419 \\
$\mathbf{5}$ & 0,1087 \\
\hline
\end{tabular}

\section{PEMBAHASAN}

Penelitian ini dilakukan dengan menganalisis kadar logam arsen (As) dan timbal $(\mathrm{Pb})$ pada minyak goreng pemakaian berulang secara spektrofotometri serapan atom (SSA). Penelitian ini bertujuan menganalisis dan menentukan kadar logam arsen (As) dan timbal $(\mathrm{Pb})$ pada minyak goreng pemakaian berulang.

Keuntungan metode spektrofotometer serapan atom (SSA) dibandingkan dengan spektrofotometer biasa yaitu spesifik, batas deteksi yang rendah dari larutan yang sama bisa mengukur unsurunsur yang berlainan, pengukurannya langsung terhadap sampel, output dapat langsung dibaca, cukup ekonomis, dapat diaplikasikan pada banyak jenis unsur, batas kadar penentuan luas dari ppm sampai \%.

Tujuan dilakukan destruksi adalah untuk merombak senyawasenyawa organik yang terdapat dalam sampel, sehingga akan diperoleh senyawa yang lebih sederhana lalu sisa $\mathrm{HNO}_{3}$ dihilangkan dengan cara dipanaskan diatas hot plate di dalam lemari asam untuk mencegah terhirupnya $\mathrm{NO}_{2}$ (racun). Kemudian sampel yang sudah didestruksi diencerkan dengan air suling hingga $50 \mathrm{~mL}$, lalu disaring dengan 
Analisis kadar Arsen (As) dan Timbal (Pb) pada minyak goreng pemakaian berulang dengan metode Spektrofotometri Serapan Atom

menggunakan kertas saring Whatman hingga diperoleh larutan jernih. Filtrat yang diperoleh digunakan untuk analisis kadar logam arsen dan timbal menggunakan alat spektrofotometri serapan atom pada panjang gelombang 193,7 nm (As) dan panjang gelombang $283 \mathrm{~nm}(\mathrm{~Pb})$.

Sampel minyak goreng diperoleh dari tiga pedagang makanan gorengan. Lokasi pedagang satu terletak di jalan Satanga, lokasi pedagang dua terletak di jalan Kapasa Raya (KIMA) dan lokasi pedagan tiga terletak di jalan Perintis Kemerdekaan 9 ,posisi ketiganya \pm 1 meter dari tepi jalan raya dan kondisi tempat penggorengannya memungkinkan terjadi paparan debu, asap dan polusi udara hal inilah yang memungkinkan terjadinya cemaran logam arsen dan timbal pada minyak goreng pemakaian berulang.

Minyak goreng digunakan dalam waktu yang cukup lama dan kebanyakan tidak menggunakan penutup untuk menghalangi pajanan udara atau asap. Pengambilan sampel bertujuan untuk mengetahui tingkat cemaran terhadap logam arsen (As) dan timbal $(\mathrm{Pb})$.

Hasil Pengukuran Serapan Larutan Baku pada logam arsen (As) Pada Panjang Gelombang 193,7 nm nilai Konsentrasinya ialah 5, 10, 15, dan 20 dan absobanya ialah 0,0120; 0,0210; 0,0339; 0,0418. Kadar logam arsen pada ketiga pedagang ialah $<0,01$ ppm dimana standar maksimum kadar logam As dalam minyak goreng adalah $0,1 \mathrm{mg} / \mathrm{kg}$.

Hasil Pengukuran Serapan Larutan Baku pada logam $\mathrm{Pb}$ (timbal) Pada Panjang Gelombang $283 \mathrm{~nm}$ nilai Konsentrasinya ialah 0,$5 ; 1 ; 1,5 ; 2$ dan 5 dan absobanya ialah 0,0103 ; 0,$0222 ; 0,0308 ; 0,0419$ dan 0,1087 (gambar 2). Kadar logam timbal sebelum penggorengan ialah $\mathrm{P} 1$ 0,1503; P2 0,3452; P3 0,1111 dan kadar logam sesudah penggorengan ialah P1 0,1940; P2 0,4005; P3 0,1788 - dimana standar maksimum kadar logam $\mathrm{Pb}$ dalam minyak goreng adalah $0,1 \mathrm{mg} / \mathrm{kg}$.

Maka dari itu perlu diwaspadai karena efek toksisnya tidak langsung terlihat setelah beberapa tahun karena sifatnya yang cenderung terakumulasi pada makhluk hidup. Sifat akumulasi inilah yang menyebabkan efeknya menjadi lebih berbahaya untuk manusia cemaran logam berat seringkali mencemari minyak goreng yang dipakai oleh pedagang gorengan, cemaran ini dapat berasal dari air, tanah, debu, udara, asap kendaraan maupun dari industri. Bila manusia 
Analisis kadar Arsen (As) dan Timbal (Pb) pada minyak goreng pemakaian berulang dengan metode Spektrofotometri Serapan Atom

mengkonsumsi minyak goreng yang tercemar logam berat terus menerus, akan terjadi akumulasi atau penumpukan logam berat tersebut dalam tubuh. Lama-kelamaan kadar logam berat ini dalam tubuh manusia mencapai tingkat yang menimbulkan keracunan yang dapat membahayakan kesehatan bahkan menimbulkan kematian.

\section{KESIMPULAN}

Berdasarkan hasil penelitian yang telah dilakukan, maka dapat disimpulkan bahwa Kadar arsen (As) pada ketiga pedagang sebelum dan sesudah penggorengannya adalah $<0,01$ ppm. Kadar timbal (Pb) sebelum dan sesudah penggorengan pada pedagang 1,2 , dan 3 adalah $(0,1503$ $\mathrm{mg} / \mathrm{kg}$ dan $0,1940 \mathrm{mg} / \mathrm{kg}), \quad(0,3442$ $\mathrm{mg} / \mathrm{kg}$ dan $0,4005 \mathrm{mg} / \mathrm{kg})$, dan $(0,1111$ $\mathrm{mg} / \mathrm{kg}$ dan $0,1788 \mathrm{mg} / \mathrm{kg}$ ).

\section{DAFTAR PUSTAKA}

1. Chairunusia, Uji Kualitas Minyak Goreng Pada Pedagang Gorengan Di Sekitar Kampus UIN Syarif Hidayatullah Jakarta (Skripsi). Jakarta: Fakultas Kedokteran Dan IImu Kesehatan Program Studi
Farmasi UIN Syarif Hidayatullah, 2013.

2. Hasibuan R, Hasan W, Naria E. Analisis Kandungan Timnbal $(\mathrm{Pb})$ Pada Minyak Sebelum dan Sesudah Penggorengan yang Digunakan Pedagang Gorengan Sekitar Kawasan Traffic Light (Skripsi). Medan, 2012.

3. Nugraha WS. Kendali Adsorben Karbon aktif dan Magnesium Silikat Dalam Efesiensi Pemakaian Minyak Goreng di Further Processing PT. Chaeroen Pokhand Indonesia-Serang", (Skripsi). Bogor: Institut Pertanian bogor. 2004.

4. Paramitha AR. Studi Kualitas Minyak Makanan Gorengan Pada Penggunaan Minyak Goreng Berulang (Skripsi). Makassar: Jurusan Teknologi Pertanian Universitas Hasanuddin, 2012.

5. Widowati W, Sastiono, Astriana, Jusuf R. Efek Toksik Logam", Yogyakarta: C.V Andi Offset, 2008.

6. Zulfiah A. Analisis Kadar Timbal $(\mathrm{Pb})$ Seng $(\mathrm{Zn})$ Dan Tembaga $(\mathrm{Cu})$ Pada lkan Bandeng ( Chanos Chanos forks) Yang Beredar Di Pinggir Jalan Porors MarosPangkep Secara Spektrofotometri Serapan Atom (Skripsi). Makassar: Fakultas Farmasi Universitas Muslim Indonesia, 2014. 